\title{
DAMPAK PENGAWASAN TERHADAP PRESTASI KERJA KARYAWAN \\ PT. PEGADAIAN PERSERO CABANG RANTAUPRAPAT

\author{
Junita Lubis
} \\ Dosen Tetap Sekolah Tinggi Ilmu Ekonomi (STIE) Labuhanbatu
}

\begin{abstract}
ABSTRAK
Metode yang digunakan dalam penelitian ini adalah deskriptif dengan pendekatan kuantitatif. Teknik pengumpulan data menggunakan wawancara, observasi, kuesioner dan dokumentasi. Metode analisis menggunakan korelasi regresi pearson dan koefisien determinasi dan uji $t$ menggunakan program bantuan SPSS 20.0 for windows. Survei tersebut mengambil sampel sebanyak 30 responden dengan kesalahan sebesar 5\%.Hasil penelitian berdasarkan tanggapan responden menyebutkan bahwa pelaksanaan supervisi tersebut berada pada kriteria good, dan prestasi kerja karyawan menunjukkan kriteria yang baik. Berdasarkan hasil analisis dapat diketahui bahwa tingkat hubungan antara pelaksanaan pengawasan dan prestasi kerja karyawan menunjukkan bahwa kedua variabel tersebut kuat dan searah. Dampak pelaksanaan pemantauan prestasi kerja karyawan diperoleh hasil 77,60\%, sedangkan sisanya 22,40\% dipengaruhi oleh faktor lainnya. Sehingga pengawasan yang lebih baik dilakukan oleh perusahaan akan memberikan dampak yang baik terhadap prestasi karyawan PT.Pegadaian Cabang Rantauprapat.
\end{abstract}

Kata Kunci: Pengawasan, Prestasi Kerja.

\section{PENDAHULUAN}

Pada umumnya perusahaan didirikan dengan harapan dapat berproduksipada tingkat yang tinggi dan dapat meningkatkan prestasi kerja karyawan secaraterus menerus. Prestasi kerja karyawan akan membawa dampak bagi karyawanyang bersangkutan maupun perusahaan tempat ia bekerja. Bagi karyawan, tingkatprestasi kerja yang tinggi dapat memberikan keuntungan tersendiri, sepertimeningkatkan gaji, memperluas kesempatan untuk dipromosikan, menurunnya kemungkinan untuk dimutasikan, serta membuat ia semakin ahli danberpengalaman dalam bidang pekerjaannya. Sebaliknya, tingkat prestasi kerjakaryawan yang rendah menunjukkan bahwa karyawan tersebut sebenarnya tidakkompeten dalam pekerjaannya, akibatnya ia sukar untuk dipromosikan ke jenjangpekerjaan yang tingkatannya lebih tinggi dan pada akhirnya dapat juga menyebabkan karyawan tersebutmengalami pemutusan hubungan kerja. 
Prestasi kerja yang tinggi akanmeningkatkan produktivitasperusahaan, menurunkan tingkat keluar masukkaryawan (turn over), serta memantapkan manajemen perusahaan. Hal utamayang dituntut oleh perusahaan dari karyawannya adalah prestasi kerja merekayang sesuai dengan standar yang telah ditetapkan oleh perusahaan.

Setiap pemimpin di dalam suatu organisasi diharuskan untuk melakukan pengawasan secara rutin agar dapat mengetahui apakah karyawan/pekerja yang ada dalam organisasi telah melaksanakan tugas sesuai dengan tanggung jawabnya. Pengawasan tersebut dilakukan agar tujuan yang telah ditetapkan oleh perusahaan dapat dilaksanakan oleh karyawan menurut prosedur yang telah ditetapkan dan untuk menghindaripenyimpangan-penyimpanganyang dapatterjadi di dalamsuatuorganisasi.

Penyimpangan di dalam organisasi merupakan penyimpangan yang dapat saja terjadi di berbagai lapisan kerja organisasi. Penyimpangan pengelolaan organisasi/perusahaan akan mempengaruhi hilangnya kesempatan yang seharusnya diperoleh dan tentu saja berdampak pada berkurangnya prestasi kerja. Secara langsung hal ini akan merugikan aktivitas organisasi. Demikian juga, secara tidak langsung akan terbangun kultur yang tidak baik bukan hanya pada hubungan internal organisasi, namun juga hubungan dengan para pihak ekternal yang menjadi mitra kerja organisasi tersebut.

Masalah yang berkaitan dengan pengawasan pada PT Pegadaian (Persero) Cabang Rantauprapat yaitu belum sepenuhnya PT Pegadaian (Persero) Cabang Rantauprapat melakukan pengawasan yang efektif, kurang pedulinya pemimpin dalam menanggapi hasil kerja karyawan. Hal lain yang menyebabkan ketidakpuasan kerja karyawan diperusahaan tersebut adalah pengawasan dari atasan yang terkesan kurang efektif dalam memberikan kenyamanan. Masalah ini dapat dilihat dari masih adanya karyawan yang tidak mampu bekerjasama dengan tim dan tidak mau membantu karyawan yang lainnya.

Untuk itu dengan jelas dapat disimpulkan bahwa peningkatan prestasi kerja karyawan sangat berhubungan dengan pegawasan yang didukung oleh kedisiplinan karyawan itu sendiri. Disamping itu usaha untuk memacu prestasi kerja pegawai, pimpinan harus berusaha menyadari hakikat dari pekerjaan karyawan. Sehingga dapat ditentukan bentuk pegwasan apa yang akan diberikan sesuai dengan kondisi kerja dan lingkungan kerja perusahaan.

Fenomena yang dijumpai saat ini untuk masing-masing variabel antara lain variabel pengawasan masih terlihat rendahnya pengawasan yang dilakukan oleh pimpinan sehingga menimbulkan tingkat disiplin kerja yang rendah pula dan mengakibatkan prestasi kerja yang dihasilkan menjadi kurang baik. Hal ini ditunjukkan oleh sebagian karyawan mau dan bersedia untuk bekerja keras, sementara karyawan yang lainnya hanya bekerja sekedarnya saja. Dampak yang jelas terlihat pada PT. Pegadaian (Persero) Cabang Rantauprapat yang mengalami penurunan sehingga mengakibatkan prestasi kerja tidak maksimal. Bentuk lain yang dapat dilihat dari rendahnya prestasi kerja pegawai adalah Disclaimer terhadap laporan hasil pemeriksaan atas laporan keuangan PT. Pegadaian (Persero) Cabang Rantauprapat, selain itu Laporan sering terlambat disampaikan, 
sehingga mendapat teguran dari pimpinan PT. Pegadaian (Persero) Cabang Rantauprapat.

Berdasarkan latar belakang diatas, maka penelitian ini mengambil judul "Dampak Pengawasan terhadap Prestasi kerja Karyawan PT. Pegadaian (Persero) Cabang Rantauprapat.

\section{TINJAUAN PUSTAKA}

\section{PENGAWASAN}

Pengawasan merupakan bagian dari fungsi manajemen yang berupaya agar rencana yang sudah ditetapkan dapat tercapai sebagaimana mestinya. Seorang pemimpin apapun jabatannya mempunyai tugas merencanakan dan mengupayakan agar rencana dapat tercapai. Tujuan pengawasan adalah merealisasi rencana maka fungsi pengawasan itu penting, sama pentingnya dengan perencanaan itu sendiri.

Menurut Manulang (2013) pengawasan adalah segala usaha dan kegiatan untuk mengetahui dan menilai kenyataan yang sebenarnya mengenai pelaksaan tugas atau kegiatan apakah sesuai dengan yang semestinya atau tidak. Suhendra (2008) menyatakan bahwa pengawasan adalah proses pengamatan dari pelaksanaan seluruh kegiatan organisasi untuk menjamin agar semua pekerjaan yang sedang dilakukan berjalan sesuai rencana yang telah ditetapkan. Handoko (2008) menyatakan bahwa pengawasan merupakan proses untuk menjamin bahwa tujuan-tujuan perusahaan dan manajemen dapat tercapai. Hal ini berkenaan dengan caracara membuat kegiatan sesuai yang direncanakan.

Dapat disimpulkan bahwa pengawasan adalah suatu proses kegiatan pimpinan yang sistematis untuk membandingkan, memastikan dan menjamin bahwa tujuan dan sasaran serta kegiatan perusahaan terlaksana dengan baik sesuai dengan standar, rencana, instruksi dan ketentuan-ketentuan yang telah ditetapkan perusahaan, serta mengambil tindakan perbaikan dan pencegahan yang diperlukan guna pemanfaatan sumber daya yang paling efektif dan efisien. antara lain:

Pane (2010), mengemukakan ada sepuluh indikator variabel pengawasan

1. Akurat, yaitu berarti informasi harus bebas dari kesalahan-kesalahan

2. Tepat waktu, Artinya informasi itu harus bersedia atau ada pada saat informasi tersebut diperlukan, tidak besok atau tidak beberapa jam lagi.

3. Obyektif, data yang benar-benar samadengan keadaan yang sebenarnya (apa adanya)

4. Terpusat pada titik pegawasan strategik

5. Realistik secara ekonomis

6. Realistik secara organisasional

7. Terkoordinasi dengan aliran kerja

8. Fleksibel

9. Bersifat sebagai petunjuk dan operasional

10. Diterima para anggota organisasi

\section{Prestasi Kerja}


Keban (2006) mengemukakan pengertian prestasi kerja merupakan pencapaian hasil yang dapat dinilai menurut prilaku yaitu hasil yang diperoleh oleh individu (kinerja individu), atau kelompok (kinerja kelompok) dan oleh suatu program atau kebijakan (kinerja program atau kebijakan). Secara umum parameter atau kriteria yang dipergunakan dalam menilai prestasi kerja meliputi kualitas, kuantitas, ketepatan waktu, penghematan biaya, kemandirian atau otonomi dalam bekerja dan kerjasama. Prestasi kerja merupakan hasil dari suatu prilaku kerja yang ditampilkan seseorang dalam melaksanakan tugas yang menjadi tanggungjawabnya.

Soedjadi (2009) mengemukakan pengertian prestasi kerja adalah hasil kerja yang dapat dicapai seseorang atau sekelompok orang dalam suatu organisasi, sesuai dengan wewenang dan tanggungjawab masing-masing dalam rangka upaya mencapai tujuan organisasi tersebut secara legal, tidak melanggar hukum dan memberikan nilai manfaat sesuai dengan moral maupun etika. Sedangkan Rivai (2010) memberikan definisi prestasi kerja sebagai prestasi yang dicapai oleh seseorang dalam melaksanakan tugasnya atau pekerjaannya sesuai dengan standar dan kriteria yang ditetapkan untuk pekerjaan itu.

Simanjuntak (2005) mengemukakan prestasi kerja setiap orang dipengaruhi oleh banyak faktor yang dapat digolongkan pada tiga kelompok, yaitu:

1. Kompetensi individu.

Kompetensi individu adalah kemampuan dan keterampilan melakukan kerja. Kompetensi setiap orang dipengaruhi oleh beberapa faktor yang dapat dikelompokkan dua golongan yaitu :

a. Kemampuan dan keterampilan kerja. Kemampuan dan keterampilan kerja setiap orang dipengaruhi oleh kebugaran fisik dan kesehatan jiwa individu yang bersangkutan, pendidikan, akumulasi pelatihan, dan pengalaman kerjanya.

b. Motivasi dan etos kerja. Motivasi dan etos kerja sangat penting mendorong semangat kerja. Motivasi dan etos kerja dipengaruhi oleh latar belakang keluarga, lingkungan masyarakat, budaya dan nilai-nilai agama yang dianutnya. Seseorang yang melihat pekerjaan sebagai beban dan keterpaksaan untuk memperoleh uang, akan mempunyai kinerja yang rendah. Sebaliknya seseorang yang memandang pekerjaan sebagai kebutuhan, pengabdian, tantangan dan prestasi, akan menghasilkan kinerja yang tinggi.

\section{Dukungan organisasi.}

Kinerja setiap orang juga tergantung dari lingkungan organisasi dalam bentuk pengorganisasian, penyediaan sarana dan prasarana kerja, serta kondisi dan syarat kerja. Pengorganisasian dimaksudkan untuk memberi kejelasan bagi setiap unit kerja dan setiap orang tentang sasaran yang harus dicapai dan apa yang harus dilakukan untuk mencapai sasaran tersebut. Penggunaan peralatan dan teknologi maju sekarang ini bukan saja dimaksudkan untuk meningkatkan kinerja tetapi juga untuk memberikan kemudahan dan kenyamanan kerja. Kondisi kerja mencakup kenyamanan di lingkungan kerja, aspek keselamatan dan kesehatan kerja, syarat-syarat kerja, system pengupahan dan jaminan sosial, serta keamanan dan keharmonisan hubungan industrial. 
3. Dukungan manajemen.

Kinerja perusahaan dan kinerja setiap orang sangat tergantung pada kemampuan pada kemampuan manajerial para manajemen atau pimpinan, baik dengan membangun sistem kerja dan hubungan industrial yang aman dan harmonis, maupun dengan mengembangkan kompetensi pekerja, demikian juga dengan menumbuhkan motivasi dan memobilisasi seluruh karyawan untuk bekerja secara optimal. Dalam rangka pengembangan kompetensi pekerja, manajemen dapat melakukan antara lain :

a. Mengidentifikasikan dan mengoptimalkan pemanfaatan kekuatan, keunggulan dan potensi yang dimiliki oleh setiap pekerja.

b. Mendorong pekerja untuk terus belajar meningkatkan wawasan dan pengetahuannya.

c. Membuka kesempatan yang seluas-luasnya kepada pekerja untuk belajar, baik secara pribadi maupun melalui pendidikan dan pelatihan yang dirancang dan diprogramkan.

Sunyoto (2013) mengenukakan pengukuran kinerja dapat berfungsi sebagai target atau sasaran, sebagai aktivitas pengukuran standar dan sebagai informasi yang dapat digunakan para karyawan, dalam mengarahkan usahausaha mereka melalui serangkaian prioritas tertentu. Prestasi kerja seseorang dapat diukur melalui:

1. Mutu kerja, berkaitan dengan ketepan waktu, keterampilan dan kepribadian dalam melakukan pekerjaan.

2. Kualitas kerja, berkaitan dengan pemberian tugas-tugas tambahan yang diberikan oleh atasan kepada bawahannya.

3. Ketangguhan, berkaitan dengan tingkat kehadiran, pemberian waktu libur dan jadwal keterlambatan hadir di tempat kerja.

4. Sikap, merupakan sikap yang ada pada karyawan yang menunjukkan seberapa jauh sikap tanggung jawab mereka terhadap sesama teman, dengan atasan dan seberapa jauh tingkat kerjasama dalam menyelesaikan pekerjaan.

Menurut Sutrisno (2012), untuk mengukur perilaku itu sendiri atau sejauhmana individu berperilaku sesuai dengan apa yang diharapkan oleh organisasi atau institusi, yaitu prestasi kerja pada umumnya dikaitkan dengan pencapaian hasil dari standar kerja yang telah ditetapkan. Pengukuran prestasi kerja diarahkan pada enam aspek yang merupakan bidang prestasi kunci bagi perusahaan yang bersangkutan. Bidang prestasi kunci tersebut adalah:

1. Hasil kerja, yaitu tingkat kuantitas maupun kualitas yang telah dihasilkan dan sejauh mana pengawasan dilakukan.

2. Pengetahuan pekerjaan, yaitu tingkat pengetahuan yang terkait dengan tugas pekerjaan yang akan berpengaruh langsung terhadap kuantitas dan kualitas dari hasil kerja.

3. Inisiatif, yaitu tingkat inisiatif selama menjalankan tugas pekerjaan khususnya dalam hal penanganan masalah-masalah yang timbul.

4. Kecakapan mental, yaitu tingkat kemampuan dan kecepatan dalam menerima instruksi kerja dan menyesuaikan dengan cara kerja serta situasi kerja yang ada.

5. Sikap, yaitu tingkat semangat kerja serta sikap positif dalam melaksanakan tugas pekerjaan.

6. Disiplin waktu dan absensi, yaitu tingkat ketepatan waktu dan tingkat 
kehadiran.

Pane, 2010 mengemukakan ada lima indikator variabel prestasi kerja, antara lain:

1. Memiliki tingkat tanggung jawab pribadi yang tinggi

2. Berani mengambil dan memikul resiko

3. Memiliki tujuan yang realistik

4. Memiliki rencana kerja yang menyeluruh dan berjuang untuk merealisasikan tujuan

5. Mencari kesempatan untuk merealisasikan rencana yang telah diprogramkan.

\section{METODE PENELITIAN}

Metode yang dilakukan penulis dalam penelitian ini adalah metodedeskriptif dengan pendekatan kuantitatif. Tujuan metode deskriptif adalah untukmembuat deskripsi, gambaran atau lukisan secara sistematis, faktual dan akuratmengenai fakta - fakta, sifat hubungan antar fenomena yang diselidiki.

Sedangkan metode kuantitatif bertujuan untuk membuat suatu uraian secara sistematis mengenai fakta-fakta dan sifat-sifat dari objek yang diteliti kemudian menggabungkan antara variabel yang terlibat didalamnya.Teknik pengambilan sampel yang digunakan dalam penelitian ini adalah teknik probability samplingdengan jenis propotionate stratified random sampling (sampel acak berstrata).

Jenis data yang dibutuhkan dalam penelitian ini adalah data primer dan data sekunder. Data primer yaitu data yang diperoleh dari responden secara langsung yang dikumpulkan melalui survey lapangan dengan menggunakan teknik pengumpulan data tertentu. Dalam penelitian ini data primer meliputi informasiyang diperoleh dari responden sebanyak 30 orang karyawan PT.Pegadaian Cabang Rantauprapat.

Dalam menganalisis data, penulis menggunakan analisis deskriptif. Analisis deskriptif dilakukan dengan menggunakan informasi-informasi yang diperoleh dari data perusahaan serta wawancara yang bersifat untuk memperjelas masalah. Untuk menjawab pertanyaan pertama dan kedua mengenai persepsi responden, maka Peneliti menggunakan kuesioner. Masing-masing disertai dengan lima kemungkinan jawaban (sangat baik, baik, cukup, tidak baik, sangat tidak baik) yang harus dipilih dan dianggap sesuai menurut responden.

Variable dalam penelitian ini adalah:

$\mathrm{X}$ : Pengawasan,

Y: Prestasi Kerja

Dengan perumusan hipotesis yaitu

H0 : $\rho \mathrm{o}=0$ Artinya, pengawasan tidak berdampak terhadap prestasi kerja karyawan

H1 $: \rho 0 \neq 0$ Artinya, pengawasan berdampak terhadap prestasi kerja karyawan.

\section{PEMBAHASAN PENELITIAN}

\section{Analisis Regresi Linier Sederhana}


Metode statistik yang digunakan untuk menguji hipotesis adalah regresi liniersederhana dengan bantuan perangkat lunakSPSS. Metode yang menghubungkan satuvariabel dependen dengan variabelindependen, sesuai hipotesis yang diuji dalampenelitian. Tabel berikut ini akan memperlihatkan hasil dari perhitungan untukanalisis regresi sederhana dari 30 responden.

\section{Uji Validitas}

Uji validitas digunakan untuk mengukur sah atau valid tidaknya suatukuesioner. Uji validitas dilakukan denganmembandingkan nilai $r$ hitung dengan $r$ tabel.Jika $\mathrm{r}$ hitung yang merupakan nilai correcteditem - total correlation $=\mathrm{r}$ tabel maka alatukur yang digunakan dinyatakan valid dansebaliknya, jika $r$ hitung $<\mathrm{r}$ tabel maka alatukur yang digunakan tidak valid. Nilai $r$ tabeldiperoleh dengan persamaan $\mathrm{N}-2=30-2=28$ (lihat tabel $\mathrm{r}$ dengSan $\mathrm{df} 28$ ) $=0,374$. Nilai rhitung dalam uji ini adalah pearson Correlationantara item dengan skor pertanyaan. Diketahui untuk nilai dalam penelitianini adalah sebesar $r$ hitung lebih besar dari $\mathrm{r}$ tabel $(0,374)$. Artinya adalah seluruh item pernyataan dinyatakan valid.

\section{Tabel 1. Uji Validitas Pengawasan}

$\begin{array}{llrll}\text { Dimensi } & \text { Indikator } & \mathrm{R} & \mathrm{R} & \\ & \text { hitung } & \text { tabel } & \text { Kesimpulan } \\ & \text { Item 1 } & 0,542 & 0,374 & \text { Valid } \\ & \text { Item 2 } & 0,501 & 0,374 & \text { Valid } \\ & \text { Item 3 } & 0,429 & 0,374 & \text { Valid } \\ & \text { Item 4 } & 0,541 & 0,374 & \text { Valid } \\ & \text { Item 5 } & 0,654 & 0,374 & \text { Valid } \\ \text { Pengawasan } & \text { Item 6 } & 0,601 & 0,374 & \text { Valid } \\ & \text { Item 7 } & 0,621 & 0,374 & \text { Valid } \\ & \text { Item 8 } & 0,560 & 0,374 & \text { Valid } \\ & \text { Item 9 } & 0,489 & 0,374 & \text { Valid } \\ & \text { Item 10 } & 0,433 & 0,374 & \text { Valid }\end{array}$

Sumber: Data primer, 2016

Tabel 2. Uji Validitas Prestasi Kerja

$\begin{array}{lllll}\text { Dimensi } & \text { Indikator } & \mathrm{R} & \mathrm{R} & \\ & & \text { hitung } & \text { tabel } & \text { Kesimpulan } \\ & \text { Item 1 } & 0,675 & 0,374 & \text { Valid } \\ & \text { Item 2 } & 0,599 & 0,374 & \text { Valid } \\ & \text { Item 3 } & 0,754 & 0,374 & \text { Valid } \\ & \text { Item 4 } & 0,409 & 0,374 & \text { Valid } \\ \text { Prestasi } & \text { Item 5 } & 0,631 & 0,374 & \text { Valid } \\ \text { kerja } & \text { Item 6 } & 0,390 & 0,374 & \text { Valid } \\ & \text { Item 7 } & 0,512 & 0,374 & \text { Valid } \\ & \text { Item 8 } & 0,578 & 0,374 & \text { Valid } \\ & \text { Item 9 } & 0,611 & 0,374 & \text { Valid } \\ & \text { Item 10 } & 0,651 & 0,374 & \text { Valid }\end{array}$


Jurnal Ecobisma Vol. 4 No. 2 Juni 2017

Sumber: Data primer, 2016 
Dari tabel pengujian validitas dengan menggunakan SPSS diatas dapat dilihat bahwasemua item pernyataan pada variabel pengawasan (X) dan prestasi Kerja Karyawan(Y) memiliki nilai corrected item totalcorrelation atau $\mathrm{r}$ hitung lebih besar dari rtabel sebesar 0,374 yang artinya dari masing-masing 10 item pernyataan pada variablepengawasan (X) dan 10 pernyataan padavariabel prestasi Kerja Karyawan (Y) dinyatakan valid dan layak digunakan.

\section{Uji Reabilitas}

Selain uji validitas, dilakukan juga ujireliabilitas kepada keseluruhan sampel yangberjumlah 30 responden. Uji reliabilitasdilakukan pada butir-butir pernyataan yang telah valid. Teknik untuk menguji reliabilitas instrument yaitu dengan menggunakan metode cronbach's alpha dimana variabel tersebut akan dinyatakan reliable dengan ketentuan

1. Apabila nilainya kurang dari 0,6 adalah kurang baik

2. Apabila nilainya 0,7 dapat diterima

3. Apabila nilainya diatas 0,8 adalah baik

Adapun hasil uji reliabilitas terhadap 30 responden dapat dilihat pada tabel berikut ini :

\section{Tabel 3. Uji Reliabilitas}

$\begin{array}{lccc}\text { Indikator } & \begin{array}{c}\text { Cronbach's } \\ \text { Alpha }\end{array} & \text { Nilai kritis } & \text { Kesimpulan } \\ \text { Pengawasan } & 0,745 & 0,6 & \text { Reliabel } \\ \text { Prestasi kerja } & 0,789 & 0,6 & \text { Reliabel }\end{array}$

Sumber: Data Olahan SPSS, 2016

Pada tabel diatas terlihat bahwa variabel pengawasan $(\mathrm{X})$ dan variable Prestasi Kerja (Y) memiliki nilai cronbach's alpha diatas 0,6. Untuk variabel pengawasan $(\mathrm{X})$ nilai cronbach's alpha sebesar 0,745 sedangkan untuk Prestasi Kerja Karyawan (Y) nilai cronbach's alpha sebesar 0,789. Hal ini bahwa variabel $\mathrm{X}$ dan $\mathrm{Y}$ tersebut telah memenuhi kriteria nilai batas dan dapat dinyatakan reliable serta layak untuk disebarkan kepada responden guna penelitian.

\section{Pengujian Hipotesis Koefisien Regresi Koefisien Determinasi}

Koefisien determinasi $\left(\mathrm{R}^{2}\right)$ adalah sebuah koefisien yang menunjukkanpersentase pengaruh semua variabel independen terhadap variabel dependen. Persentase tersebut menunjukkan seberapa besar variabel independen (pengawasan)dapat menjelaskan variabel dependennya(Prestasi Kerja 
Karyawan). Semakinbesar koefisien determinasinya, semakin baikvariabel dependen dalam menjelaskan variableindependennya. Dengan demikian persamaanregresi yang dihasilkan baik untuk mengestimasi nilai variabel dependen.

Untuk mengetahui besarnya pengaruh variabel independen dapat dilihat pada tabel berikut ini :

Tabel 4. Koefisien Determinasi

Model Summary ${ }^{b}$

\begin{tabular}{|l|r|r|r|r|}
\hline Model & \multicolumn{1}{|c|}{$\mathrm{R}$} & R Square & \multicolumn{1}{|c|}{$\begin{array}{c}\text { Adjusted R } \\
\text { Square }\end{array}$} & $\begin{array}{r}\text { Std. Error of } \\
\text { the Estimate }\end{array}$ \\
\hline 1 &, $723^{\mathrm{a}}$ &, 776 &, 668 & 3,102 \\
\hline
\end{tabular}

a. Predictors: (Constant), pengawasan

b. Dependent Variable: prestasi kerja

Berdasarkan hasil perhitungan koefisien determinasi dapat diasumsikanbahwa besarnya pengaruh Pengawasan terhadap Prestasi kerja karyawan padaPT.Pegadaian Cabang Rantauprapat adalah 77,60\%, yang termasukke dalam kategori pengaruh yang Tinggi atau Kuat. Untuk lebih jelasnya dapatdilihat pada tabel berikut :

Tabel 5. Tinggi Rendahnya Koefisien Determinasi

\begin{tabular}{cl} 
Pernyataan & \multicolumn{2}{c}{ Keterangan } \\
$<4 \%$ & Pengaruh Rendah Sekali \\
$5 \%-16 \%$ & $\begin{array}{l}\text { Pengaruh Rendah tapi } \\
\text { Pasti }\end{array}$ \\
$17 \%-$ & Pengaruh cukup Berarti \\
$49 \%$ & \\
$50 \%-$ & Pengaruh Tinggi atau \\
$81 \%$ & Kuat \\
$>82 \%$ & Pengaruh Tinggi Sekali
\end{tabular}

Sementara sisanya sebesar $22,40 \%$ dipengaruhi oleh faktor-faktor lain diluar pengawasan, yaitu kompensasi, motivasi kerja, disiplin kerja,pengembangan karir dan lain-lain.

\section{Uji Signifikan Individu (Uji t)}

Uji t dilakukan untuk mengetahui masing-masing variabel bebas terhadapvariabel terikat secara parsial atau individual.Untuk menjawab hipotesis yang telahdiajukan, maka dilakukan uji t. Adapun rumushipotesis statistiknya : $\mathrm{H} 0: \rho \mathrm{o}=0$ Artinya, pengawasan tidak berdampak terhadap prestasi kerja karyawan 
$\mathrm{H} 1: \rho 0 \neq 0$ Artinya, pengawasan berdampak terhadap prestasi kerja karyawan.

Dengan kriteria pengujian :

-Jika t hitung < t tabel maka Ho diterima dan Ha ditolak

-Jika t hitung > t tabel maka Ho ditolakdan Ha diterima

Uji t dilakukan denganmembandingkan t hitung dengan tabel padataraf signifikan $0,05 / 2=0.025$ dengan derajatkebebasan $\mathrm{T}$ tabel $=\mathrm{n}-\mathrm{k}-1$ : alpha/ $2=30-1-1$ : $0,05 / 2=30: 0,025=2,048$

Keterangan : $\mathrm{n}$ : jumlah, $\mathrm{K}$ : jumlah variabel bebas, 1 : konstan

Diketahui t hitung $(4,342)>\mathrm{t}$ tabel $(2,048)$ dan Sig. $(0,000)<0,05$. Artinya adalahbahwa variabel pengawasan berpengaruh signifikan terhadap Prestasi karyawan PT.Pegadaian Cabang Rantauprapat.

\section{DAFTAR PUSTAKA}

Ghozali , Imam, 2007. Aplikasi Analisis Multivariat Dengan Program SPSS. Edisi Kelima Badan Penerbit Universitas Dipenogoro, Semarang.

Handoko T. Hani (2008), "Manajemen Personalia Dan Sumberdaya Manusia”. Edisikedua. BPFE Yogyakarta, Yogyakarta :

Keban. 2006. Manajemen Sumber Daya Manusia. Jakarta: Djambatan.

M. Manullang. 2013. Pengantar Bisnis. Jakarta: PT. Indeks.

Pane,Akhmad Fauzi.2010. Analisis Persepsi Dan Sikap Konsumen Terhadap Produk Mountea Garuda Food. Institut Pertanian Bogor. Bogor.

Rivai, Veithzal. 2010. Performance Appraisal Sistem Yang Tepat untuk Menilai Kinerja Karyawan dan Meningkatkan Daya Saing Perusahaan. Jakarta: PT. Rajagrafindo Persada.

Santoso, Singgih., 2007. SPSS Statistik Multivariat. PT. Elex Komputindo KelompokGramedia, Jakarta.

Simanjuntak, Payaman J. 2006. Manajemen dan Evaluasi Kinerja. Jakarta: Lembaga Fakultas Ekonomi Universitas Indonesia.

Sunyoto, Danang. 2013. Teori, Kuisioner, dan Analisis Data Sumber Daya Manusia (Praktik Penelitian). Yogyakarta: Center for Academic Publishing Service.

Sutrisno, Edy. 2012. Manajemen Sumber Daya Manusia. Jakarta: Kencana Prenada Media Group 